\title{
Spanish palygorskites: geological setting, mineralogical, textural and crystal-chemical characterization
}

\author{
MERCEDES SUÁREZ ${ }^{1, *}$, JAVIER GARCÍA-RIVAS ${ }^{1,2}$, JUAN MORALES SÁNCHEZ-MIGALLÓN $^{3}$ and \\ EMILIA GARCÍA-ROMERO ${ }^{2,4}$ \\ ${ }^{1}$ Departamento de Geología, University of Salamanca, Plaza de la Merced s/n, 37008 Salamanca, Spain \\ *Corresponding author, e-mail: msuarez@usal.es \\ ${ }^{2}$ Instituto de Geociencias (IGEO), Complutense University of Madrid and CSIC, C/ José Antonio Nováis 2, \\ 28040 Madrid, Spain \\ ${ }^{3}$ Instituto de Geología Económica Aplicada, University of Concepción, Casilla 160-C, Concepción, Chile \\ ${ }^{4}$ Department of Crystallography and Mineralogy, Complutense University of Madrid, C/ José Antonio Nováis 2, \\ 28040 Madrid, Spain
}

\begin{abstract}
A representative group of palygorskites from the six most important Spanish deposits and six other occurrences were studied comparing their mineralogy, textural features, crystal-chemistry, and surface properties. These palygorskites have different geological origin: (1) sedimentary in large Tertiary continental basins, (2) hydrothermally altered volcanic rocks in the southern Spanish Peninsula, also Tertiary in age; and (3) fault-hosted pure palygorskites. The most common impurities are quartz and carbonates, both calcite and dolomite, but also feldspar, illite, smectite, and sepiolite have been identified. The structural formulae obtained show great variability between samples, as well as with respect to the theoretical formula for palygorskite, as they range from magnesian to aluminous palygorskites. The most common fibre length ranges between 1 and $10 \mu \mathrm{m}$ but the palygorskites of hydrothermal origin are much longer, with lengths over $10 \mu \mathrm{m}$. The shorter fibres give rise to tightened textures, while longer fibres usually generate more open textures. These properties, along with the degree of compaction, condition the porosity of the sample, which in turn influences its surface properties. The specific surface areas obtained range between $30 \mathrm{~m}^{2} \mathrm{~g}^{-1}$ and $263 \mathrm{~m}^{2} \mathrm{~g}^{-1}$, depending on the impurities content and on the texture and crystal-chemistry; the highest values correspond to Mg-rich palygorskite.
\end{abstract}

Key-words: palygorskite; hydrothermal palygorskite; clay minerals; Tertiary Spanish basins; mineral assemblage; structural formula; texture; surface properties; SEM; adsorption of $\mathrm{N}_{2}$.

\section{Introduction}

Palygorskite is an important industrial mineral used in numerous industrial and commercial products that are mostly dependent on the physical and chemical sorptive, rheological and molecular sieve properties of the mineral (Alvarez, 1984; Jones \& Galán, 1988; Murray, 2000; Alvarez et al., 2011; López-Galindo et al., 2011; Murray et al., 2011). Their uses are specifically related to their surface properties as a consequence of their structural and microtextural features. Palygorskite, a modulated phyllosilicate, has modulated components in octahedral sheets. As sepiolite, it can be described as 2:1 type ribbons, or polysomes, running parallel to the $\mathbf{c}$ axis. The polysomes are connected by oxygen atoms. The oxygen planes are continuous, but the periodic inversion of the apical oxygen every two tetrahedral chains limits the lateral dimensions of the octahedral sheet. Palygorskite and sepiolite are minerals that have particular structural and textural features in which the presence of structural cavities (tunnels and channels), silanol groups on the external surface, and different types of water molecules determine their surface properties and ability to interact with many compounds, leading to the formation of nanostructured materials (Ruiz-Hitzky et al., 2011).

Ideal palygorskite has an intermediate tri-dioctahedral character $(80 \%$ of the octahedral positions are occupied). Its ideal structural formula, based on the model of Bradley (1940), is $\mathrm{Si}_{8} \mathrm{O}_{20}\left(\mathrm{Al}_{2} \mathrm{Mg}_{2} \square\right)(\mathrm{OH})_{2}\left(\mathrm{OH}_{2}\right)_{4}\left(\mathrm{H}_{2} \mathrm{O}\right)_{4}$ for a half unit cell. However, a broad compositional variation has been found (García-Romero \& Suárez, 2010) and a continuous polysomatic series has been reported between sepiolite and palygorskite, with no compositional gap (Suárez \& García-Romero, 2011). An earlier classification of palygorskites distinguished three types (Suárez et al., 2007). Type I: ideal palygorskite, which has an octahedral composition near Bradley's structural formula, with similar $\mathrm{Al}$ and $\mathrm{Mg}$ contents and negligible substitutions. Type II: the most common palygorskite, which has a less than ideal octahedral $\mathrm{Al}$ content and a higher $\mathrm{Mg}$ content, 
but the number of octahedral cations per half unit cell (i.e. per formula unit, pfu) remains close to 4 (i.e. one vacant octahedral position). Although Al may be partially substituted by $\mathrm{Fe}$ (III) and/or Mg, this specific type of palygorskite has a dioctahedral character. Type III: Mgpalygorskite, which is a trioctahedral variety. The number of octahedral cations is higher than 4 (i.e. there is less than one vacant octahedral position). A further type was introduced by García-Romero \& Suárez (2010), Type IV: Al-palygorskite is a palygorskite having $\mathrm{Al} / \mathrm{Mg}>1$ and defined by a total number of octahedral cations per half unit cell $<4$, with $\mathrm{Mg}<2$, and consequently $\left(\mathrm{Al}+\mathrm{Fe}^{3+}\right)>$ Mg. Recently, Suárez \& García-Romero $(2011,2013)$ proposed the existence of intergrowth between palygorskite and sepiolite polysomes in all possible proportions, leading to a continuous polysomatic series, thus explaining the high variability found in the chemical composition and properties of these minerals. The previously described palygorskite types are therefore related to the proportion of sepiolite polysomes in palygorskite, because the amount of $\mathrm{Mg}$ in the palygorskite empirical formula is actually related to the sepiolite polysome content. The existence of a continuous polysomatic series between sepiolite and palygorskite is related to their growth by aggregation (García-Romero \& Suárez, 2014).

Palygorskite, like sepiolite, is an authigenic mineral formed by the neoformation or transformation of precursor minerals (Galán \& Pozo, 2011). Palygorskite is common in lacustrine and soil environments (Paquet, 1970; Singer, 1979, 1984; Mackenzie et al., 1984; Shadfan \& Dixon, 1984; Suárez et al., 1994) in arid or semi-arid climatic conditions, when the interstitial and overlying fluids are alkaline $(8<\mathrm{pH}<9)$ with high $\mathrm{Si}$ and $\mathrm{Mg}$ activities (Singer \& Norrish, 1974; Watts, 1976, 1980; Callen, 1977; Hutton \& Dixon, 1981; Estéoule-Choux, 1984; Jones \& Galán, 1988; Birsoy, 2002). Usually, it is associated with carbonates, evaporites and chert and with other Mg-rich clays, such as saponite, kerolite and stevensite. Palygorskite is also described in calcretes as minor diagenetic constituent (Eren et al., 2008; Kaplan et al., 2013; Kadir et al., 2014). The best condition for its formation appears to be in lacustrine-palustrine environments, as repeatedly reported (Millot, 1970; Trauth, 1977; Singer, 1979; Galán \& Castillo, 1984; Jones, 1986; Jones \& Galán, 1988; Webster \& Jones, 1994; Calvo et al., 1999; Galán \& Pozo, 2011; Akbulut \& Kadir, 2003). In addition, palygorskite can originate by direct precipitation from solutions (Singer, 1979, 1984; Singer \& Norrish, 1974) or from a smectite precursor (Sautereau \& Decarreau, 1973; Decarreau et al., 1975; Yaalon \& Wieder, 1976; Couture, 1977; Trauth, 1977; Weaver \& Beck, 1977; El Prince et al., 1979; Galán \& Ferrero, 1982; Velde, 1985; Tazaki et al., 1986, 1987; Suárez et al., 1994; Jamoussi et al., 2003).

Previous studies have presented evidence for significant structural and compositional differences among palygorskites from different localities and genetic conditions. As the surface properties of palygorskite are a consequence of their structural and microtextural features, the aim of this study is to characterize a group of Spanish palygorskites from different deposits, comparing their mineralogy, textural, and surface properties. This group of palygorskites may be considered a good example of the variability affecting the crystal-chemistry and properties of this mineral.

\section{Materials and methods}

A representative group of palygorskites from the six most important Spanish deposits as well as six other occurrences was studied, comparing their mineralogical and textural features. The samples are labelled with the first letters of the closest named locality to the deposit (Fig. 1). They have different geological origins, mainly sedimentary, but also hydrothermal. The studied deposits occur in (1) large Tertiary continental basins: the Duero Basin (samples BER, NAV and PED), Guadalquivir Basin (LEB), and Tajo Basin (ESQ, TAB and TEM); (2) a small basin in the Monfragüe National Park, Caceres Province (TOR); (3) hydrothermally altered volcanic rocks in the southern Spanish Peninsula (BUH and TRA), also Tertiary in age; and (4) as fault-hosted pure palygorskite (NIJ and SEG). Several samples from each deposit were studied; the data reported correspond to representative samples. Figures S1 and S2 (freely available as Supplementary Material linked to this article at https://pubs.geoscience world.org/eurjmin/) show the current appearance of the deposits, which, except for Bercimuel (BER) and Tembleque (TEM), are no longer exploited.

Mineralogical characterization was conducted by X-ray powder diffraction of the whole-rock sample and of the $<2 \mu \mathrm{m}$ fraction obtained by decantation and studied as oriented aggregates under ambient conditions, after solvation with ethylene glycol and heating to $550{ }^{\circ} \mathrm{C}$. A Siemens D-500 XRD diffractometer with $\mathrm{CuK \alpha}$ radiation and graphite monochromator was employed, from $2^{\circ}$ to $65^{\circ}$ by steps of $0.025^{\circ}$ and $3 \mathrm{~s} / \mathrm{step}$ counting time for the whole rock, and from $2^{\circ}$ to $40^{\circ}$ for the oriented aggregates, by steps of $0.05^{\circ}$ and $1 \mathrm{~s} / \mathrm{step}$. A semi-quantitative estimate of the mineral proportions (by weight) was made using the Reflection Power Method and the reflection powers given by Martín Pozas (1968).

Particle morphology and textural relationships were established by using scanning electron microscopy (SEM) and transmission electron microscopy (TEM). The SEM observations were performed using a JEOL JSM-6330F field-emission microscope, operating at $10 \mathrm{kV}$ and equipped with a Link System energy dispersive X-ray (EDX) microanalyser. Prior to SEM examination, freshly fractured surfaces of representative samples were air dried and coated with Au under vacuum.

The chemical composition was obtained using analytical electron microscopy (AEM) with TEM, in samples of great purity, with two different microscopes, a JEOL 2000 FX instrument at an acceleration voltage of $200 \mathrm{kV}$ and a JEOL 3000 FX field-emission microscope at $300 \mathrm{kV}$. Both microscopes incorporate an OXFORD ISIS EDX spectrometer 


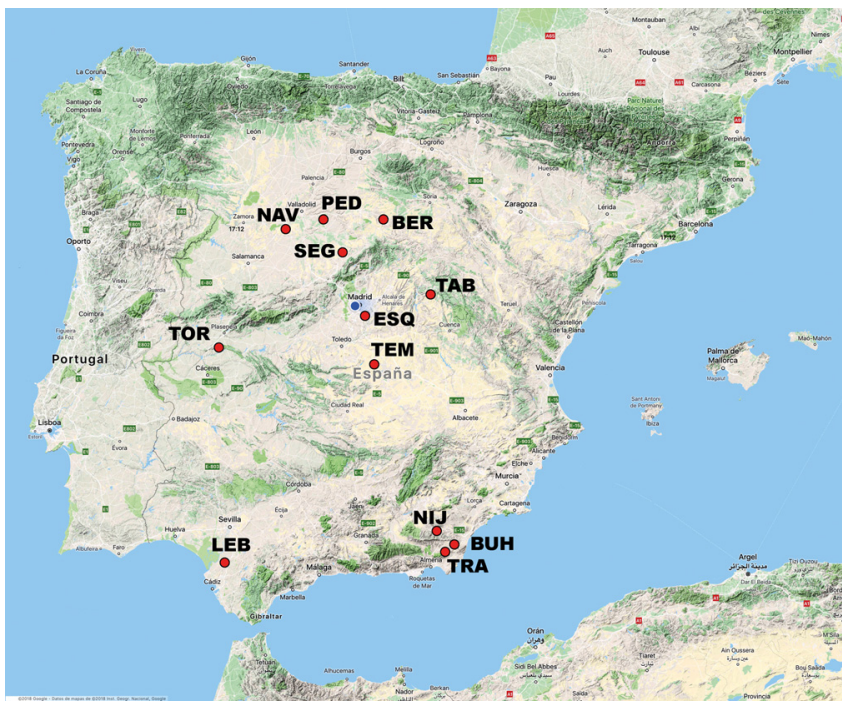

Fig. 1. Location map of the studied deposits in the Iberian Peninsula.

$(136 \mathrm{eV}$ resolution at $5.39 \mathrm{keV})$, equipped with its own software for quantitative analysis. The TEM samples were prepared by depositing a drop of diluted suspension on a microscopic grid with collodion and coated with Au.

Textural analyses were performed from the nitrogen adsorption-desorption isotherms at $-196{ }^{\circ} \mathrm{C}$, obtained from a static-volumetric apparatus (Micromeritics ASAP 2010 adsorption analyser). All samples were pre-treated and analysed in the same way: $0.3 \mathrm{~g}$ of the raw sample powdered in a manual mortar were out-gassed for $10 \mathrm{~h}$ at room temperature, and then for $4 \mathrm{~h}$ at $110^{\circ} \mathrm{C}$ to reach a lesser pressure of $\leq 2 \mu \mathrm{m} \mathrm{Hg}$. The isotherms were obtained following a previously fixed 40 -point $\mathrm{P} / \mathrm{P}_{0}$ table, and the reproducibility of the isotherms was checked.

\section{Results and discussion}

\subsection{Geology and mineralogy}

The samples studied come from deposits that are spatially distributed across Spain (Fig. 1).

BER, Bercimuel (Segovia). This deposit is located in the central part of the Iberian Peninsula, on the southeastern border of the Duero Basin, in an intracratonic depression running south-east north-west within the Duero Neogene Basin. The deposit lies in Neogene sediments, in the distal facies of alluvial fans that fill the small Tertiary basin of the Riaza River. It outcrops near the village of Bercimuel, on a hill, presenting a high lateral continuity and thickness that varies between 4 and $15 \mathrm{~m}$; only the first $6-8 \mathrm{~m}$ are rich in palygorskite. The deposit is bound at the bottom by a calcareous crust and at the top by an erosive terrace of the Riaza River. Evidence of pedogenetic processes are abundant at the palygorskite level.

This deposit originally corresponded to the confluence zone of two alluvial fan systems that come from the Sierra de Honrubia and Somosierra (Fernandez Macarro et al.,
1988). The palygorskite has its origin in post-sedimentary processes (Suárez et al., 1989) that are related to the partial dissolution and transformation of illite-smectite precursors, as shown by TEM (Suárez et al., 1994, 1995).

The deposit is currently mined by the MYTA Company; a general view of the quarry and location of the five study samples is shown in Fig. S1a. Palygorskite is the main mineral at the bottom of the exploited level and decreases progressively towards the top of the deposit (Fig. 2a) at the same time that the inherited minerals, quartz and mica/ illite, increase, so that only the first $\sim 6 \mathrm{~m}$ are rich in palygorskite $(60-80 \%)$. Small amounts of calcite, feldspar, smectites, chlorite and interstratified minerals also appear (Suárez et al., 1995). The samples BER1 to BER5, from bottom to top, illustrate this gradual variation in mineral content. A sample from the bottom, rich in palygorskite $(\sim 80 \%)$, was selected for further study.

$L E B$, Lebrija (Sevilla). The deposit is located in the southwestern Iberian Peninsula at the boundary between the provinces of Cadiz and Sevilla. It is part of the Guadalquivir Basin, a large structural unit that is mainly filled by Tertiary and Quaternary marine and continental sediments. Palygorskite and sepiolite are found in the Pliocene continental sediments, in a lacustrine environment of perimarine origin. The deposit and its origin are described in detail in Galán \& Ferrero (1982). Two units are distinguished: the lowest has a maximum thickness of $30 \mathrm{~m}$ and is mainly composed of marls that contain sepiolite and palygorskite as well as some clayey interbedded layers rich in sepiolite. The upper unit, named "the palygorskite bed" due to its high contents of that mineral, has a thickness $\leq 15 \mathrm{~m}$. The palygorskite layers range from $0.30 \mathrm{~m}$ to $3 \mathrm{~m}$ in thickness and are interbedded with limestone and marl. The origin of palygorskite is hypothesized to be a neoformation and transformation of previous minerals, which could be controlled by periodic climate changes (Galán \& Ferrero, 1982).

Five samples from the Lebrija deposit, corresponding to the top of the upper unit, were studied in this work; they show the vertical and lateral variations of the outcropping materials (Fig. S1b). As shown in Fig. 2b, calcite (15-50\%) is the main impurity that appears with palygorskite. The palygorskite contents range from $\sim 45$ to $80 \%$ in the studied samples. There are small amounts of quartz and dolomite, and sepiolite appears in small proportions in sample LEB-5, corresponding to an intermediate term of the sepiolite-palygorskite series according to Suárez \& García-Romero (2011, 2013). The sample richest in palygorskite (LEB-3) was selected for crystal-chemical and textural studies.

NAV, Nava del Rey (Valladolid). The deposit also occurs in the Duero Basin and was exploited until the late 1970s. There have been no comprehensive studies of this deposit, and the only reference to it is in Pineda et al. (2007). Palygorskite appears in a calcareous-crust unit that developed over a conglomeratic level and is dated as Lower Miocene, and these carbonate crusts are edaphic developments on sediments of fluvial origin. The deposit is situated on a hill-top formed by a conglomerate, 


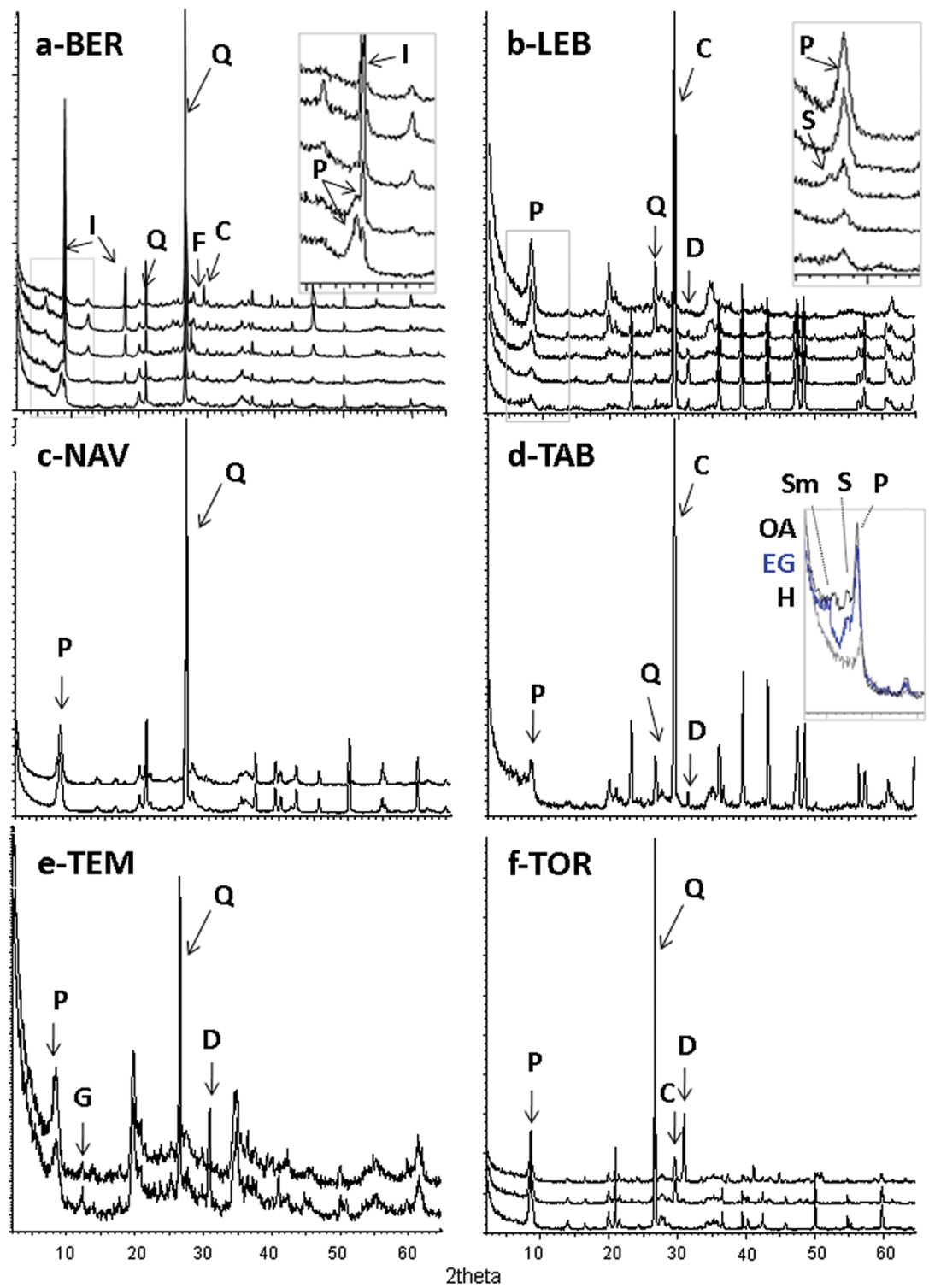

Fig. 2. X-ray diffraction patterns. P, palygorskite; I, illite; Q, quartz; F, feldspar; C, calcite; D, dolomite; S, sepiolite; G, gypsum; OA, oriented aggregate; EG, oriented aggregate solvated with ethylene glycol; $\mathrm{H}$, oriented aggregate heated at $550{ }^{\circ} \mathrm{C}$. a) Lebrija; b) Bercimuel; c) Nava del Rey; d) Tabladillo; e) Tembleque and f) Torrejón.

resulting in a residual relief; it has a maximum thickness of $5 \mathrm{~m}$ (Fig. S1c). The conglomerate bears centimetric clasts of quartz and quartzite, mainly in a white, very hard carbonate-free matrix-cement. Although Pineda et al. (2007) describe the layer as a carbonate crust, there is no carbonate (calcite or dolomite) in the studied samples, but instead a type of palycrete, as described by Rodas et al. (1994) and Stahr et al. (2000). According to Rodas et al. (1994) the origin of palygorskite in these materials is related to the movement of alkaline phreatic waters. X-ray diffractograms of two representative samples are shown in Fig. 2c; both samples are nearly identical, with $\sim 75 \%$ palygorskite and $25 \%$ quartz.

TAB, Tabladillo (Guadalajara). The deposit is located in the Tajo Basin on its eastern border. After
Benayas et al. (1960), palygorskite occurs in the Alcarria formation, which is dated as OligoceneMiocene. The Oligocene in this formation is constituted of a complex in which some palygorskite levels are intercalated, along with sepiolite. In the Miocene deposits, two units are distinguished; the lower is dated as Burdigalian-Vindobonian, and the upper is dated as Pontian. Palygorskite-sepiolite appear in the lower unit, related to gypsiferous marls (Martín Pozas et al., 1981). These authors studied six samples corresponding to clayey layers between 0.4 and $2 \mathrm{~m}$ thick, with a palygorskite content ranging from 30 to $65 \%$. Palygorskite appears together with sepiolite (10-20\%), smectite, calcite and quartz and is related to neoformation processes. 


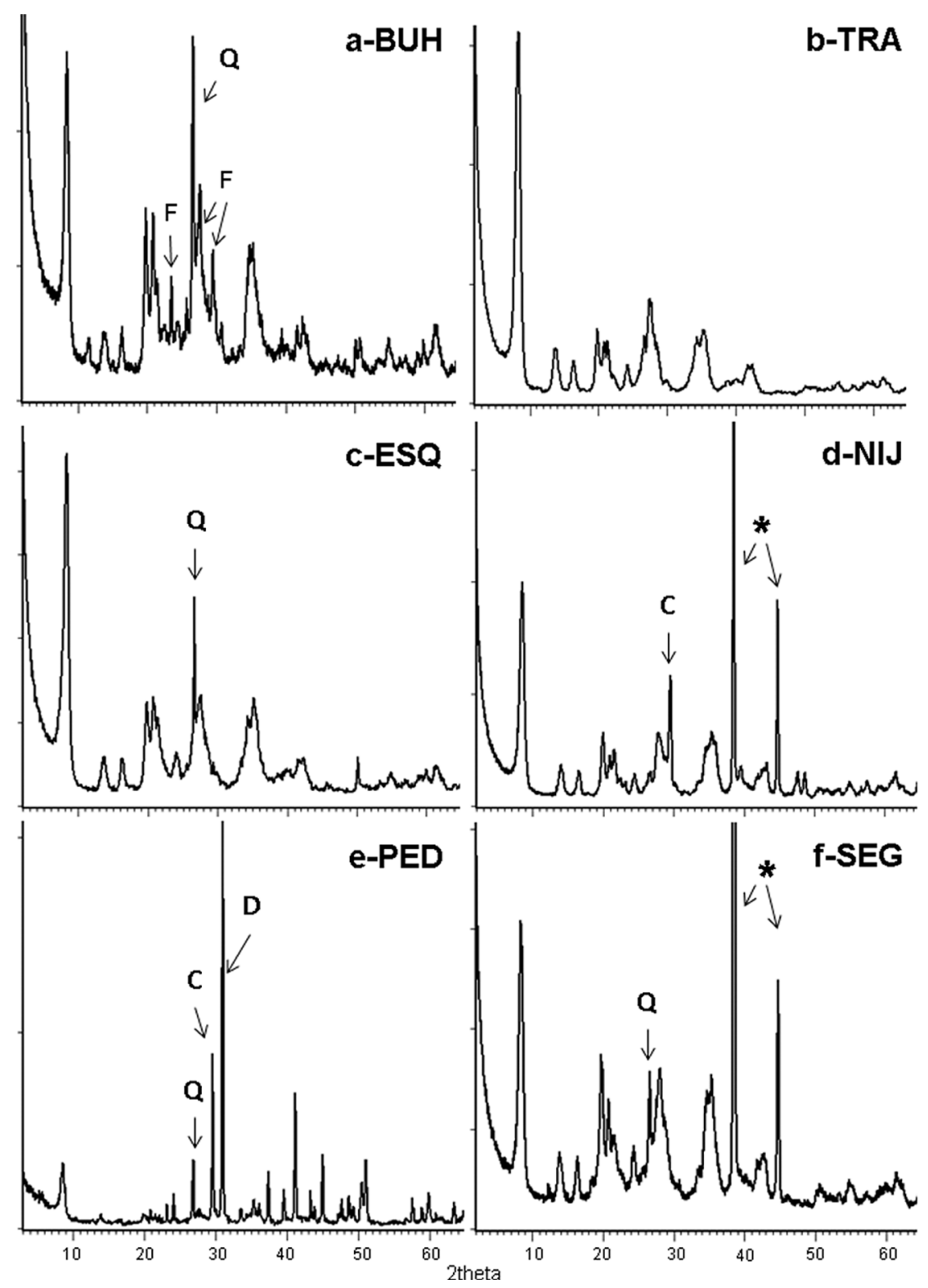

Fig. 3. X-ray diffraction patterns. Q, quartz; F, feldspar; C, calcite; D, dolomite. * Al holder. A) Buho; B) Trancos; c) Esquivias; d) Nijar; e) Pedrajas de San Esteban and f) Segovia.

Currently, the deposit is nearly inaccessible because the quarry and all of the outcropping material have been covered with removed materials (Fig. S1d and e), so it is not possible to observe the spatial relationships among the material. Only one sample could be collected from the outcrop, and the identified minerals are in good agreement with those identified by Martín Pozas et al. (1981); therefore, the sample could be considered to be representative of the deposit. In the corresponding diffraction pattern (Fig. S1d), calcite is the main impurity to palygorskite, together with quartz, dolomite, sepiolite and smectite. Palygorskite + sepiolite constitute $\sim 65 \%$ of the sample.

TEM, Tembleque (Toledo). This deposit is the property of the Clariant Company. It is located in southeastern TajoBasin. Palygorskite is found in the Miocene "Red clays with levels of gypsum" unit, in which intercalations of gypsum in reddish clays are more abundant towards the top of the unit. To our knowledge, there are no previous references of this deposit.

The Clariant Company exploits a clayey reddish level that is rich in palygorskite with evidence of pedogenetic processes (Fig. S2a and b). These clays contain dispersed centimetric crystals of secondary gypsum. The palygorskite outcrops appear at the top of a small hill in a partially eroded layer that is $\sim 6 \mathrm{~m}$ in maximum thickness. The palygorskite content ranges between 75 and $85 \%$. Quartz is the main impurity (15-10\%) together with small amounts of gypsum $(<5 \%)$ and dolomite $(<10 \%)$ at the bottom of the layer (Fig. $2 \mathrm{e})$. A sample from the top of the outcrop that is slightly richer in palygorskite $(\sim 85 \%)$ was selected for further study. 
TOR, Torrejón el Rubio (Cáceres). This deposit is located in the western Iberian Peninsula, in the Tertiary basin of Torrejón, which is separated from the Tajo basin by a significant quartzite relief (the Miravete, Corchuelas and Extranjera Sierras). Three units are distinguished: the basement, a detrital-clayey bed and the "raña," which consists of clayey slates that vary from brownish to pinkish. The detrital-clayey bed is formed by an alternation of sand and gravel with clays and carbonates. Finally, the "raña" is a reddish fanglomerate with quartzite pebbles originating from alluvial fans and piedmont alluvial plains that expanded just before the development of the current rivers (Martínez Lope et al., 1995). Palygorskite appears in the basement as well as the detrital-clayey bed, and its origin is linked to the alteration of the Cambrian slates from the basement (Galán \& Castillo, 1984). The palygorskite bed has a maximum thickness of $8 \mathrm{~m}$, but the average thickness is $3 \mathrm{~m}$. The highest concentration ( 75 to $85 \%$ ) is in the centre of the basin (Murray et al., 2011). The impurities consist of quartz, calcite, dolomite, chlorite, montmorillonite, kaolinite and mica (Galán et al., 1975). Its formation occurred by direct precipitation from $\mathrm{Si}-, \mathrm{Al}$ - and $\mathrm{Mg}$-rich solutions, from the alteration of the basement chlorite-rich slates (Galán \& Castillo, 1984; Murray et al., 2011). The three samples studied here correspond to a horizontal sampling at the top of the palygorskite layer (Fig. 3c). The mineral content of the three samples present some variations regarding the carbonate content: calcite appears in two samples $(5-10 \%)$ and dolomite only appears in sample TOR-3 (15\%). Quartz is present in the three samples, between 25 and $30 \%$. The palygorskite content ranges between 55 and $75 \%$ (Fig. 2f); the purest sample was used to characterize the crystal-chemistry and textural properties.

In addition to these main deposits, other occurrences were also studied.

BUH, Buho and TRA, Los Trancos (Almeria). Both occurrences are located in Cabo de Gata (Almería), in the southeastern Iberian Peninsula. These palygorskite occurrences are associated with the important deposits of bentonites of this region (Leone et al., 1983), formed by the hydrothermal alteration of cineritic materials (GarcíaRomero, 2012). As shown in Fig. 3a, the sample from Buho contains small amounts of quartz and feldspar (microcline), while those from Los Trancos are pure (Fig. 3b); Fig. S2b shows the appearance of the Buho occurrence.

ESQ, Esquivias (Toledo). This small deposit is located in the centre of the Iberian Peninsula. Occurrence of palygorskite in this area has been reported repeatedly (Leguey et al., 1985; Pozo et al., 1985; García-Romero, 1988; Bustillo \& García-Romero, 2003; García-Romero et al., 2004; García-Romero \& Suárez, 2010), in the lacustrine and distal alluvial fans deposits of the Intermediate Unit (Miocene) of the Madrid Basin, part of the Tajo Basin. To the northeast of the town of Esquivias, thin argillaceous beds are interlayered with calcrete/palustrine limestones. Palygorskite occurs together with calcite and other minerals, mainly sepiolite, smectites and opal (Bustillo \& García-Romero, 2003). The origin of this palygorskite is from direct precipitation of interstitial waters present in the calcrete/palustrine limestones. The sample studied here corresponds to the top of the deposit, where palygorskite appears to be almost pure, as shown in Fig. S2e, with only small amounts of quartz $(<5 \%$; Fig. 3c). Palygorskite from this layer has been previously studied by García-Romero \& Suárez (2010) and Stathopoulou et al. (2011).

NIJ, Serrata de Nijar (Almería). After García-Romero et al. (2006), this palygorskite occurrence of the southeastern Iberian Peninsula is a fault-hosted palygorskite. The palygorskite fibres grow along fault planes in outcrops of a large fault zone in SE Spain (Carboneras Fault Zone) by a hydrothermal process occurring along the Serrata de Nijar and surrounding areas (Fig. S2f). This palygorskite is almost pure, with only small amounts of calcite ( 2\%; Fig. 3d).

PED, Pedrajas de San Esteban (Duero Basin, Valladolid, Spain). Layers rich in palygorskite appear at the top of the sedimentary series, just under the unit known as Paramo Limestone, and are associated with both calcareous and dolomitic marls (Fig. S2g and h). The material studied here is representative of these palygorskite-rich marly layers, in an outcrop close to the locality of Pedrajas de San Esteban. The marls are Upper Miocene in age and result from sedimentation in high-salinity seasonal ponds under semiarid climatic conditions, as demonstrated by the presence of gypsum pseudomorphs. Palygorskite occurs together with calcite, dolomite and minor amounts of quartz (Fig. 3d). These layers contain frequent mixtures of sepiolite and palygorskite and are intermediate in terms of the sepiolite-palygorskite series (Suárez \& García-Romero, 2011, 2013). The representative sample selected is composed of palygorskite $(\sim 70 \%)$ with carbonates, both calcite and dolomite, and minor quartz.

SEG, Segovia (Segovia). The sample studied was collected south of the city of Segovia, to the southeast of the Duero Basin, and is associated with plutonic rock where palygorskite is filling fracture planes. Crusts of palygorskite were collected along the trench of a highspeed railway (Fig. S2i). It is an almost pure palygorskite with only trace quartz (Fig. 3f).

\subsection{Texture}

All the samples studied contain palygorskite as the main mineral and, in some cases, the only mineral present, as indicated by X-ray diffraction patterns (Figs. 2 and 3). The most common impurities are quartz, calcite and other clay minerals: illite, smectite and sepiolite.

All the studied palygorskites have the same characteristic fibrous aspect under the SEM. Images representative of the studied deposits are shown in Figs. 4, 5 and 6, where it is possible to observe the signature of each deposit. Images in Figs. 4 and 5 are at the same magnification and show a remarkable difference in the length and curl of the fibres. García-Romero \& Suárez (2013) proposed a morphological classification of sepiolite and palygorskite 

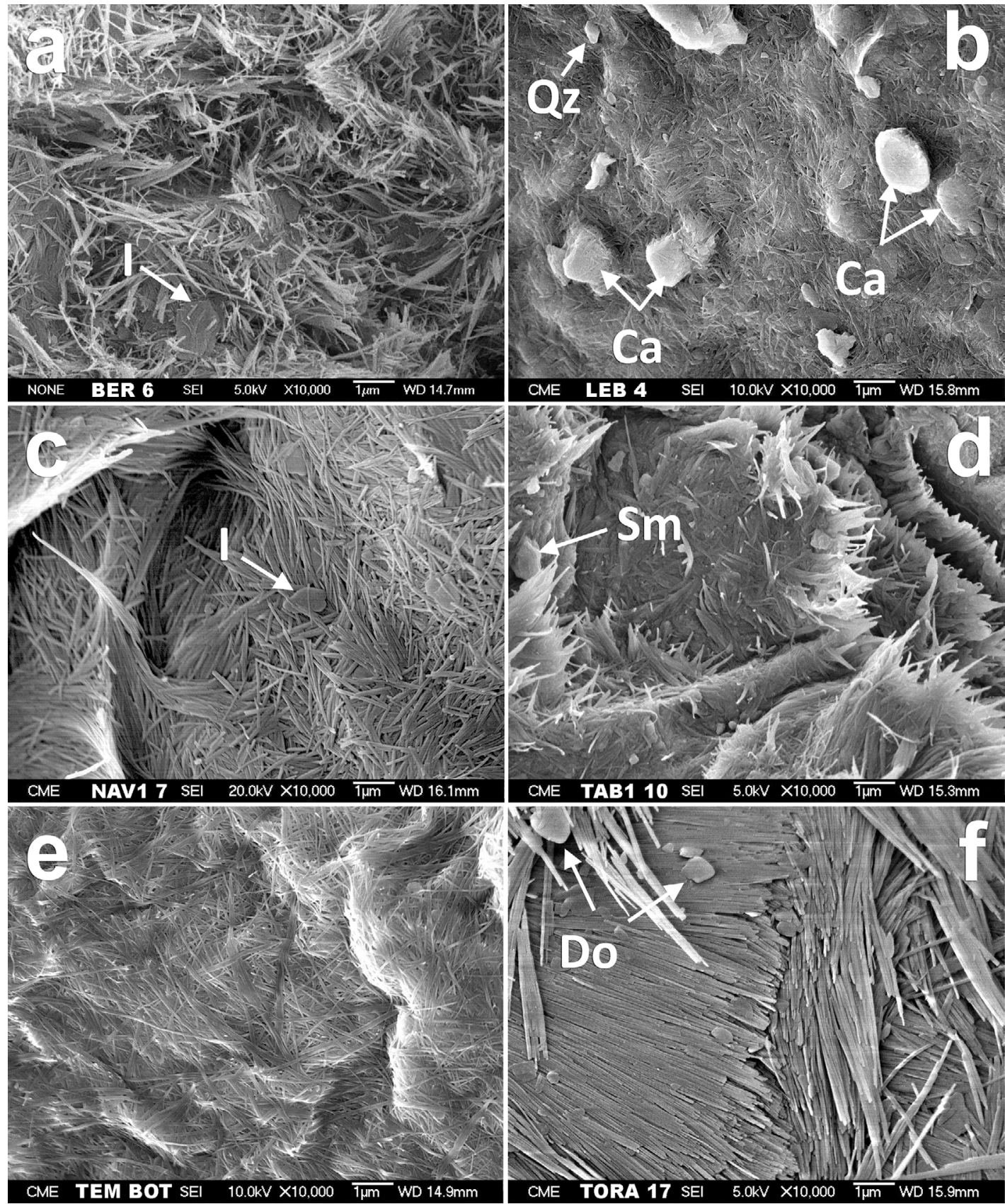

Fig. 4. SEM micrograph showing general views. a) Bercimuel; b) Lebrija; c) Nava del Rey; d) Tabladillo; e) Tembleque and f) Torrejón el Rubio. I, illite; Qz; quartz; Ca, calcite; Sm, smectite; Do, dolomite.

fibres according to length, length/width relation, and curliness. They concluded that there is a continuous variation in fibre length with no apparent gap from less than $1 \mu \mathrm{m}$ to centimetres (macroscopic fibres).

The most common palygorskite fibre length in the deposits studied here ranges between 1 and $10 \mu \mathrm{m}$ (Figs. 4, 5 and 6, and Table 1), i.e. group 2-intermediate, according to the classification of García-Romero \& Suárez (2013). All samples except those from Lebrija (LEB), Buho (BUH), Níjar (NIJ), Segovia (SEG) and Los Trancos (TRA) belong to this group of "intermediate fibres". Shorter fibres, with a length under $1 \mu \mathrm{m}$, are found in the Lebrija (LEB) and Buho
(BUH) deposits, which are classified as group 1. Samples collected from Níjar (NIJ), Segovia (SEG) and Los Trancos (TRA), whose origin is linked to hydrothermal events, have much longer fibres, with lengths over $10 \mu \mathrm{m}$, but not quite macroscopic. In addition to the different lengths, the fibres also have different bending or curliness. The shortest (group 1) are straight. Samples that belong to group 2 (intermediate fibres: between 1 and $10 \mu \mathrm{m}$ ) are generally straight, as in the, Nava del Rey (NA), Tembleque (TEM), or Esquivias (ESQ) deposits, but may be slightly curved, as in the Bercimuel (BER), Tabladillo (TAB) or Pedrajas de San Esteban (PED) deposits. The longest fibres are curved (Nijar(NIR), Segovia 

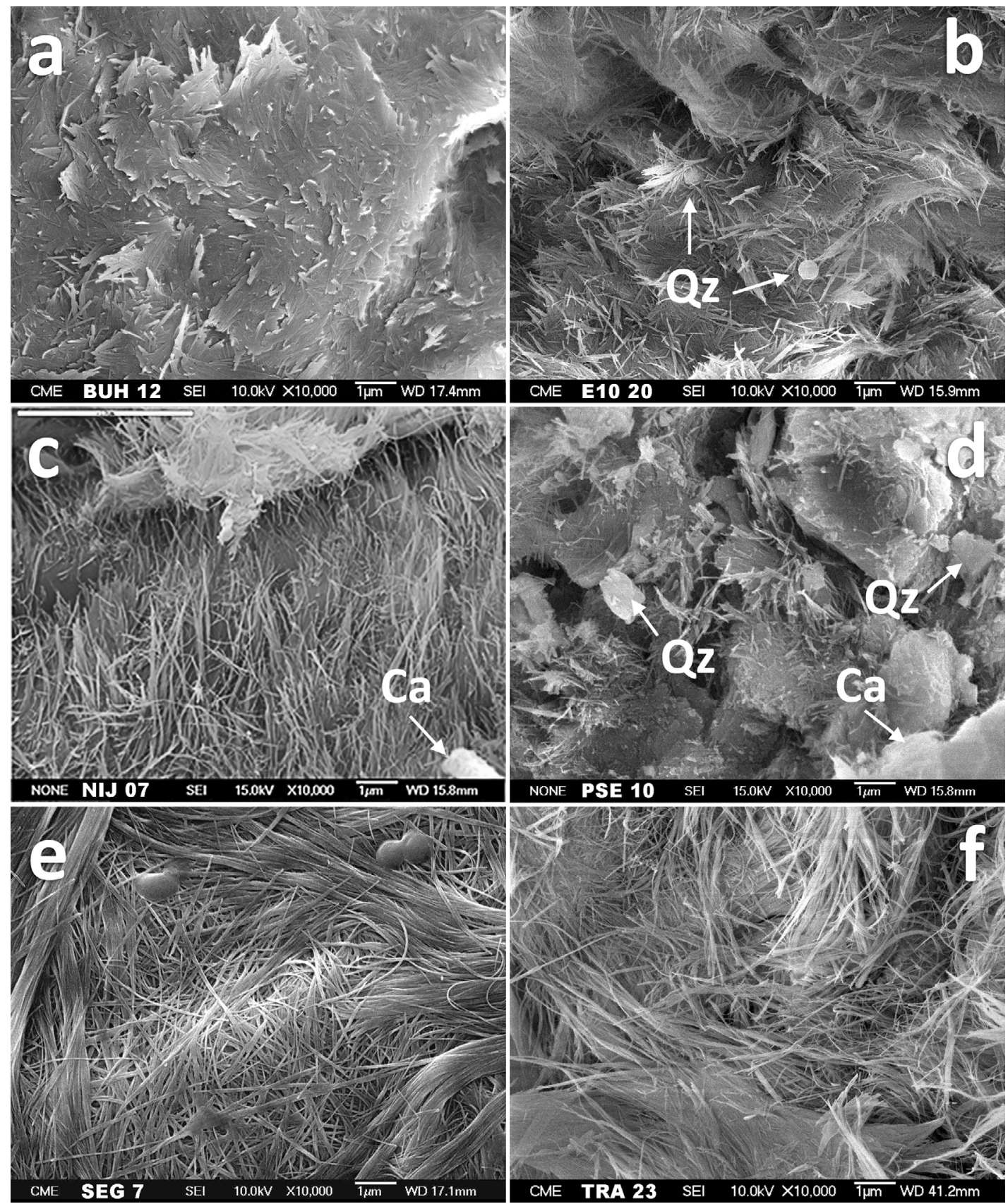

Fig. 5. SEM micrograph showing general views. a) Buho, b) Esquivias, c) Nijar, d) Pedrajas de San Esteban, e) Segovia, and f) Trancos. Qz, quartz; $\mathrm{Ca}$, calcite.

(SEG) and Los Trancos (TRA)). Only one of the deposits (Torrejon El Rubio (TOR)) has extremely rigid fibres, and none of the studied samples is curly.

In addition, the shorter fibres give rise to tight textures, as in LEB, TAB, TEM, BUH, while longer fibres usually generate more open textures, as in SEG, NIJ and TRA.

Some impurities observed by SEM-FEG may give interesting clues about their genetic relationship. These impurities may not be homogeneously distributed. They are usually concentrated in some areas in the samples, and their concentrations may be so low that they are undetected by XRD. Figure $6 a$ and $b$ shows palygorskite fibres (samples from ESQ and LEB) grown among carbonate crystals in a close genetic relationship. By contrast, Fig. 6c and $\mathrm{d}$ shows detrital quartz among the palygorskite fibres, and detrital micas occur in BER sample (Fig. 6e).

\subsection{Palygorskite crystal-chemistry}

The chemical compositions obtained by point analysis using AEM allow us to calculate the structural formulae of these palygorskites (Table 2 and Table S1 in supplementary materials). The results obtained show great variability between samples, as well as with respect to the ideal formula. 

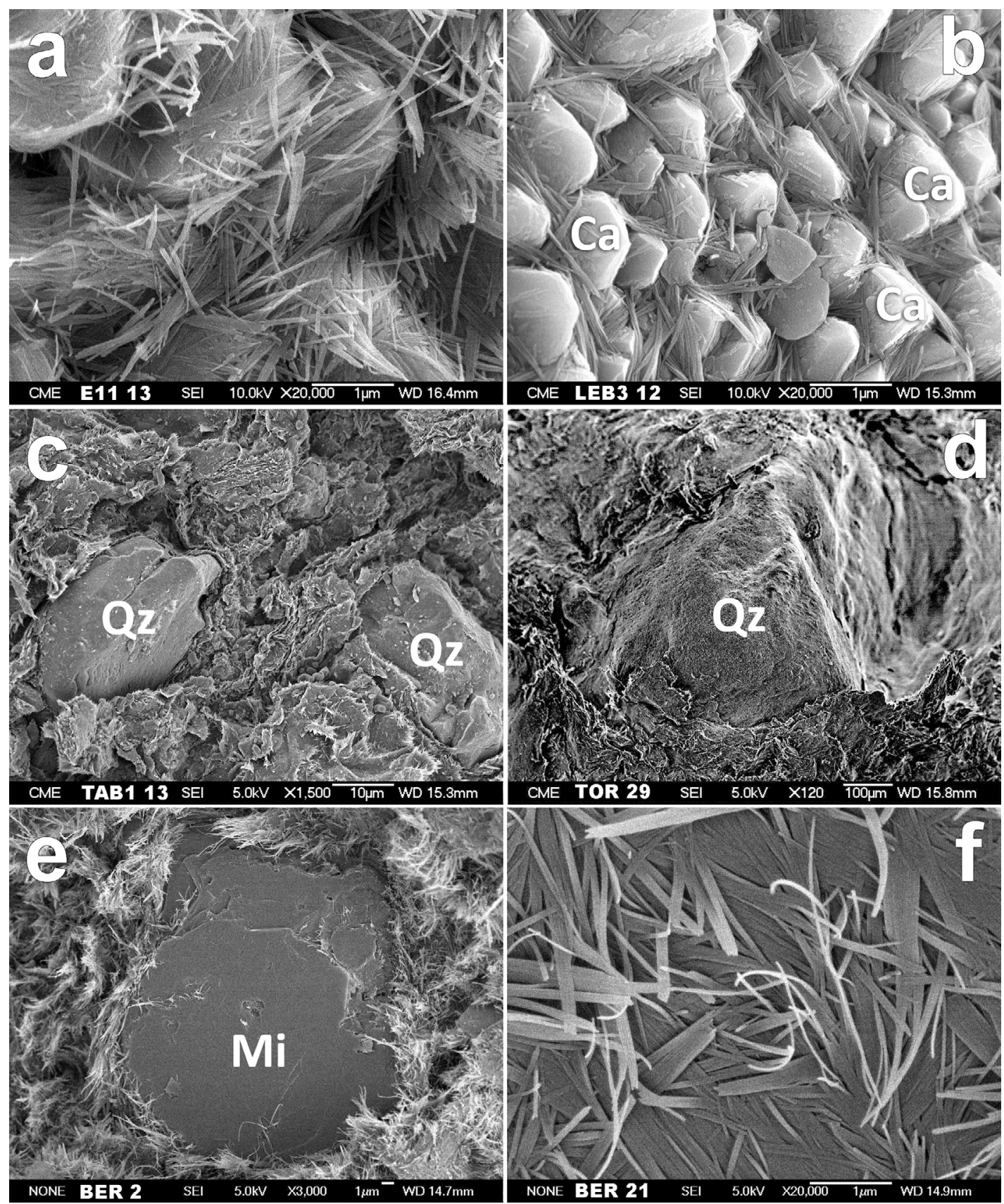

Fig. 6. SEM micrograph. a and b) Palygorskite fibres (samples from ESQ and LEB) grown among carbonate crystals in a close genetic relationship. $\mathrm{c}$ and d) Detrital quartz among the palygorskite fibres; e) detrital mica in the BER sample; $\mathrm{f}$ ) Palygorskite fibres in the BER sample. Ca, calcite; Qz, quartz; Mi, mica.

The sample from Nijar(NIJ) is closest in composition to ideal palygorskite. All samples, except TRA, show some tetrahedral substitution of $\mathrm{Al}$ for $\mathrm{Si}(\mathrm{Si}<8 \mathrm{pfu})$.

Regarding the contents of the octahedral layer, the samples are separated in two clearly different groups: ESQ, TRA, TAB, TOR and PED show a stronger trioctahedral character (sum of octahedral cations $>4 \mathrm{pfu}$ ) due to their higher $\mathrm{Mg}$ content. These samples are of Type III or magnesian palygorskites (according to Suárez \&
García-Romero, 2011) and therefore correspond to intermediate terms of the sepiolite-palygorskite polysomatic series. Samples LEB, TEM, BUH, BER, NIJ, SEG and NAV have less than 4 octahedral cations pfu and are subdivided into two additional groups: those classified as Type II, or ordinary palygorskites, as previously mentioned, and others classified as Type IV, or aluminous palygorskites (LEB, BUH, and TEM), according to Suárez \& García-Romero (2011). 
Table 1. Locations, label, and textural characteristic of the studied palygorskites.

\begin{tabular}{|c|c|c|c|c|c|c|}
\hline & Location & Label & $\%$ palygorskite & Impurities & Fibre length $(\mu \mathrm{m})$ & Curl \\
\hline \multirow{4}{*}{ Deposits } & Lebrija (Sevilla) & LEB & $45-80$ & Q-Ca-Sp-Do & $<1$ & Straight \\
\hline & Tabladillo (Guadalajara) & TAB & $30-65$ & Q-Ca-Sm-Sp & $1-10$ & Curved \\
\hline & Tembleque (Toledo) & TEM & $75-85$ & Q-Do- $<$ Gy & $1-10$ & Straight \\
\hline & Torrejón el Rubio (Cáceres) & TOR & $75-85$ & Q-Do- $<$ Ca & $1-10$ & Rigid \\
\hline \multirow{4}{*}{ Occurrences } & Níjar (Almería) & NIJ & 98 & $<\mathrm{Ca}$ & $\gg 10$ & Curved \\
\hline & Pedrajas de San Esteban (Valladolid) & PED & 70 & $\mathrm{Ca}-\mathrm{Do}-<\mathrm{Q}$ & $1-10$ & Curved to straight \\
\hline & Segovia & SEG & 98 & $<\mathrm{Q}$ & $\gg 10$ & Curved \\
\hline & Los Trancos (Almería) & TRA & 100 & - & $\gg 10$ & Curved \\
\hline
\end{tabular}

Table 2. Structural formulae obtained from the mean chemical compositions and fitted to 21 negative charges (point analyses and mean chemical compositions from Table S1 in Supplementary Materials).

\begin{tabular}{lllllllll}
\hline Sample & $\mathrm{Si}$ & ${ }^{\mathrm{IV}} \mathrm{Al}$ & ${ }^{\mathrm{VI}} \mathrm{Al}$ & $\mathrm{Fe}^{3+}$ & $\mathrm{Mg}$ & $\Sigma_{\text {oct }}$ & $\mathrm{Ca}$ & $\mathrm{K}$ \\
\hline BER & 7.88 & 0.12 & 1.61 & 0.40 & 1.98 & 3.99 & 0.05 & 0.04 \\
BUH & 7.77 & 0.23 & 1.87 & 0.32 & 1.72 & 3.91 & 0.07 & 0.10 \\
ESQ & 7.93 & 0.07 & 1.13 & 0.19 & 2.87 & 4.19 & 0.05 & 0.07 \\
LEB & 7.44 & 0.56 & 1.59 & 0.60 & 1.49 & 3.68 & 0.11 & 0.27 \\
NAV & 7.99 & 0.01 & 1.43 & 0.22 & 2.25 & 3.90 & 0.26 & 0.02 \\
NIJ & 8.02 & - & 1.79 & 0.17 & 2.02 & 3.98 & 0.01 & 0.01 \\
PED & 7.88 & 0.12 & 1.17 & 0.25 & 2.83 & 4.25 & 0.07 & 0.05 \\
SEG & 7.91 & 0.09 & 2.02 & 0.05 & 1.82 & 3.89 & 0.07 & 0.01 \\
TAB & 8.03 & & 1.46 & 0.27 & 2.40 & 4.13 & 0.05 & 0.12 \\
TEM & 7.43 & 0.57 & 1.97 & 0.49 & 1.41 & 3.87 & 0.11 & 0.10 \\
TOR & 7.34 & 0.66 & 1.30 & 0.40 & 2.61 & 4.31 & 0.02 & 0.15 \\
TRA & 8.02 & - & 1.24 & 0.15 & 2.83 & 4.22 & 0.05 & 0.16 \\
\hline
\end{tabular}

According to Suárez et al. (2007), the difference in ionic radius between the octahedral cations produces variations in the $d$-spacing of some families of lattice planes, such that the content of the octahedral layer can be calculated by using XRD data and the following formulae:

$$
\begin{aligned}
& { }^{\mathrm{VI}} \mathrm{Al}=49.1617-7.4401 d_{200} \\
& \mathrm{OV}=24.0047-3.6065 d_{200}
\end{aligned}
$$

where $\mathrm{OV}$ is the number of vacant octahedral positions. The contents of octahedral Al calculated using formula (1) and those obtained through AEM are compared in Fig. 7. As shown, except for sample PED, there is a very good agreement between both ranges of data.

\subsection{Surface properties}

Taking into account that the main industrial applications of palygorskite are based on its surface properties, we have studied these features on a representative sample of each deposit. The BET method (Brunauer et al., 1938) using $\mathrm{N}_{2}$ at $77 \mathrm{~K}$ as adsorbate was applied and the specific surface area (SSA), the micropore area, and external area were determined. The results obtained from the analysis of the isotherms of $\mathrm{N}_{2}$ are given in Table 3. All the isotherms obtained correspond to type II, according to the IUPAC classification (Thommes et al., 2015), because they do not have limit adsorption at relative pressures close to 1 , and they have hysteresis loop of type H3-H4. This indicates that these samples have pores in all ranges of porosity: micro, meso and macropores.

The BET surfaces obtained are very different and range between $30 \mathrm{~m}^{2} \mathrm{~g}^{-1}$ and $263 \mathrm{~m}^{2} \mathrm{~g}^{-1}$ for the PED and ESQ samples, respectively. It is evident that the presence of variable amounts of impurities within the samples influences the final SSA, depending on the content and nature of these impurities. For example, the three samples with higher impurity content (PED, TAB, and NAV) have lower SSA. However, the intrinsic characteristic of palygorskite also greatly influences the final SSA value; as observed in Table 3, there is a large difference in SSA values obtained for samples with similar palygorskite contents. For instance, samples NAV and TOR contain $\sim 75 \%$ palygorskite and have SSAs of 40 and $105 \mathrm{~m}^{2} \mathrm{~g}^{-1}$, respectively. In the same way, pure or almost pure samples ( $>95 \%$ of palygorskite), such as BUH, ESQ, NIJ, SEG, and TRA, have SSA values that range between $117 \mathrm{~m}^{2} \mathrm{~g}^{-1}$ and $263 \mathrm{~m}^{2} \mathrm{~g}^{-1}$. This variability in SSA was also found in previous studies.

The lowest values of SSA reported for palygorskite are $48 \mathrm{~m}^{2} \mathrm{~g}^{-1}$ (from Jebel Rheouis, Rusmin et al., 2016) and $49 \mathrm{~m}^{2} \mathrm{~g}^{-1}$ (from Hudson, Islem et al., 2016); in these two 


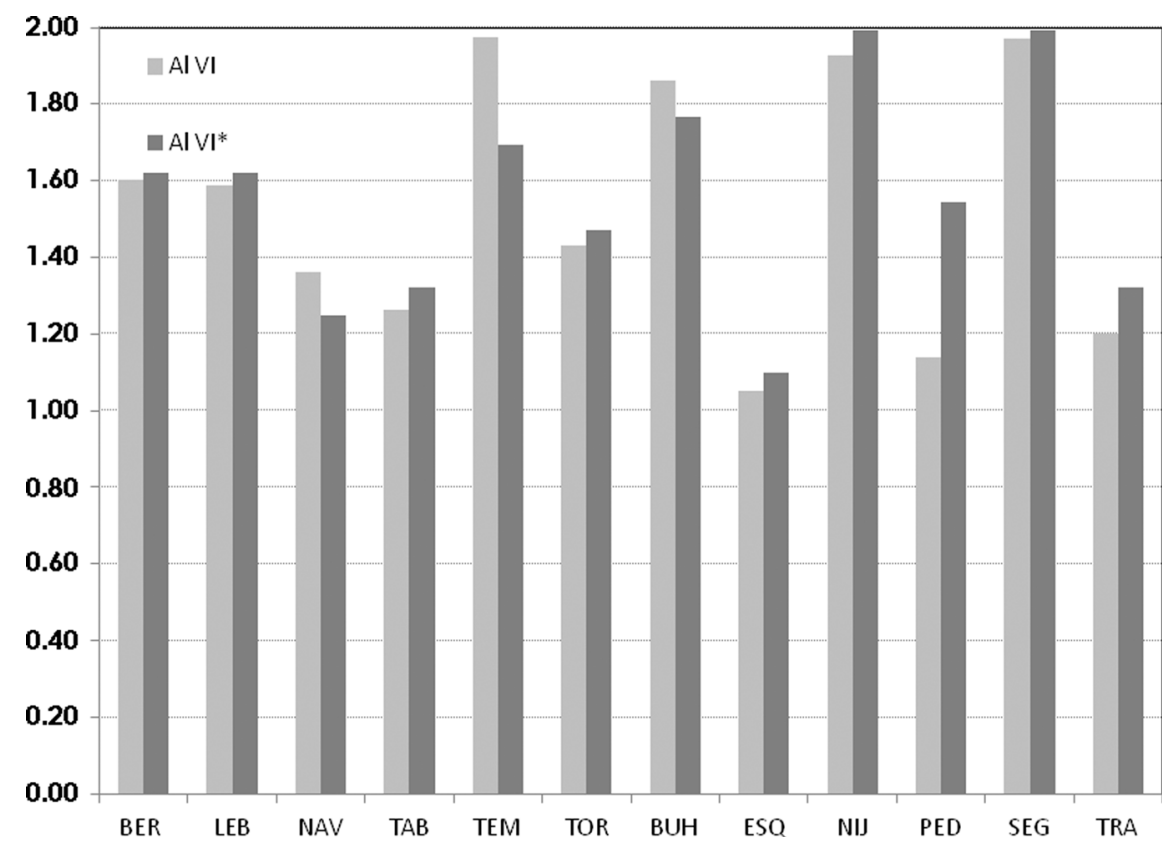

Fig. 7. Number of octahedral Al pfu (i.e. per half unit-cell) calculated from AEM data (Al VI) and from XRD data according to formula (1) in text (Al VI*).

cases the palygorskite occurs with dolomite as main impurity. The highest SSA, $268 \mathrm{~m}^{2} \mathrm{~g}^{-1}$, was reported by Rusek et al. (2009) for a Russian palygorskite from an unknown locality. Most palygorskites have SSA between 100 and $200 \mathrm{~m}^{2} \mathrm{~g}^{-1}$. There are many factors that influence the SSA value. The samples can have different impurities, most frequently quartz, feldspar, and carbonates (calcite and dolomite), that do not contribute to the SSA, but also sepiolite and smectites which also can have good surface properties. The texture can also highly influence the surface properties, as shown for sepiolite in a comparative study (Suárez \& García-Romero, 2012). In addition to these intrinsic characteristics (impurities and texture) that can differ even for samples from a same deposit, the pretreatment of the samples (grinding, outgassing, etc.) also influences the SSA. For instance, SSA values of palygorskite from Hudson (Australia) vary between $48 \mathrm{~m}^{2} \mathrm{~g}^{-1}$ and $87 \mathrm{~m}^{2} \mathrm{~g}^{-1}$ (Rusmin et al., 2016, and Liu et al., 2016, respectively), while palygorskite from Jiangsu (China) vary between $138 \mathrm{~m}^{2} \mathrm{~g}^{-1}$ and $216 \mathrm{~m}^{2} \mathrm{~g}^{-1}$ (Shi et al., 2016, and $\mathrm{Xu}$ et al., 2011, respectively). Palygorskite from Torrejón (Spain), studied in the present work, has been reported with $146 \mathrm{~m}^{2} \mathrm{~g}^{-1}$ (Galan, 1996) and $112 \mathrm{~m}^{2} \mathrm{~g}^{-1}$ (Lindgreen et al., 2008). The influence of the pre-treatments was shown by Liu et al. (2012) who found values between $153 \mathrm{~m}^{2} \mathrm{~g}^{-1}$ and $215 \mathrm{~m}^{2} \mathrm{~g}^{-1}$ depending on the grinding time. In this work all samples have been pre-treated in the same way and therefore the results obtained are comparable and have to be attributed to the mineralogy and texture of the samples.

Consistently with SSA, the micropores surface also varies for palygorskites from different localities; in all samples studied here the microporosity area is lower than the external area, except for TOR. The highest values of the microporosity, $94 \mathrm{~m}^{2} \mathrm{~g}^{-1}$ and $84 \mathrm{~m}^{2} \mathrm{~g}^{-1}$, have been reported for a palygorskite from Anhui, China (Liu et al., 2012; Wang et al., 2015), respectively, both from China. In our samples (Table 3 ), the highest values of micropores surface correspond to the Mg-palygorskites ESQ $\left(110 \mathrm{~m}^{2} \mathrm{~g}^{-1}\right)$ and TRA $\left(94 \mathrm{~m}^{2} \mathrm{~g}^{-1}\right)$. The presence of sepiolite polysomes in these samples, an intermediate composition in the polysomatic series (Suárez \& GarcíaRomero, 2011, 2013), implies the existence of a certain amount of wider intracrystalline channels, with highest accessibility to the $\mathrm{N}_{2}$ molecules, and therefore higher structural microporosity. Besides, the microporosity of palygorskite (as well as sepiolite) is not only related to the presence of structural tunnels and channels, but also to the microtexture, as bundles of almost parallel fibres (like TOR and BER samples in Figs. 4e and 6f) have inter-fibre micropores (Suárez \& García-Romero, 2012).

\section{Final remarks}

From the comparative study of the six most important Spanish deposits of palygorskite and six other occurrences it is possible to conclude that:

- they were formed in different geological environments: sedimentary (sedimentation in large Tertiary continental basins), hydrothermal (hydrothermal alteration of volcanic rocks) and also as fault-hosted;

- palygorskite occurs with quartz and carbonates as the main impurities, but feldspars, illite, sepiolite and smectite are also frequent; 
Table 3. Textural data obtained from the $\mathrm{N}_{2}$ isotherms.

\begin{tabular}{lccc}
\hline & $\mathrm{S}_{\text {BET }}\left(\mathrm{m}^{2} \mathrm{~g}^{-1}\right)$ & $\mathrm{S}_{\text {ext }}\left(\mathrm{m}^{2} \mathrm{~g}^{-1}\right)$ & $\mathrm{S}_{\text {mic }}\left(\mathrm{m}^{2} \mathrm{~g}^{-1}\right)$ \\
\hline BER & 168 & 92 & 76 \\
BUH & 117 & 97 & 20 \\
ESQ & 263 & 153 & 110 \\
LEB & 150 & 123 & 27 \\
NAV & 40 & 34 & 6 \\
NIJ & 125 & 78 & 47 \\
PED & 30 & 26 & 4 \\
SEG & 173 & 120 & 53 \\
TAB & 52 & 39 & 13 \\
TEM & 177 & 149 & 29 \\
TOR & 105 & 51 & 54 \\
TRA & 251 & 143 & 94 \\
\hline
\end{tabular}

- the deposits show a great crystal-chemichal variability between samples but also with respect to the palygorskite ideal formula (ranging from magnesian to aluminous palygorskites), even for deposits of similar geological origin;

- texturally, most palygorskites have fibre sizes between 1 and $10 \mu \mathrm{m}$ but those whose origin is linked to hydrothermal events (hydrothermal ambience or faulthosted) are much longer, with lengths over $10 \mu \mathrm{m}$;

- the specific surface areas also greatly vary (range between $30 \mathrm{~m}^{2} \mathrm{~g}^{-1}$ and $263 \mathrm{~m}^{2} \mathrm{~g}^{-1}$ ). The surface properties depend, as logical, on the impurities but they also depend on the texture and crystal-chemistry;

- the highest specific surface values correspond to the Mgrich palygorskite. This is related to the presence of sepiolite polysomes intergrown with palygorskite, since sepiolite channels are wider than palygorskite channels and contribute to a higher microporosity;

- considering that the deposits have numerous local heterogeneities depending on the collection site, each sample has its unique features (length, curliness, degree of aggregation and compaction, porosity), which are a consequence of the particular genetic conditions. Consequently, these textural differences provide variations in the physicochemical properties.

Acknowledgement: The authors are very grateful to Selahattin Kadir and an anonymous reviewer for their helpful comments. Financial support for this work was provided by MINECO (CGL2016-77005-R). Javier GarcíaRivas thanks the MINECO grant (BES-2013-065092).

\section{References}

Akbulut, A. \& Kadir, S. (2003): The geology and origin of sepiolite, palygorskite and saponite in Neogene lacustrine sediments of the Serinhisar-Acıpayam basin, Denizli, SW Turkey. Clays Clay Miner, 51, 279-292.

Alvarez, A., (1984): Sepiolite properties and uses. in: "Palygorskite-Sepiolite: Occurrences, Genesis and Uses". Developments in Sedimentology, A. Singer \& E. Galán, eds., Elsevier, New York, 253-287.
Alvarez, A., Santarén, J., Esteban-Cubillo, A., Aparicio, P. (2011): Current industrial applications of palygorskite and sepiolite. in: "Developments in Palygorskite-Sepiolite research". Developments in Clay Science, 3, E. Galán \& A. Singer, eds., Elsevier, New York, 281-298.

Benayas, J., Pérez Mateos, J., Riba, O. (1960): Asociaciones de minerales detríticos en los sedimentos de la Cuenca del Tajo. Anales Edaf. Agrobiol., 11, 633-670.

Birsoy, R., (2002): Formation of sepiolite-palygorskite and related minerals from solution. Clays Clay Miner., 50, 736-745.

Bradley, W.F. (1940): Structure of attapulgite. Am. Mineral., 25, 405-410.

Brunauer, S., Emmett, P.H., Teller, E. (1938): Adsorption of Gases in Multimolecular Layers. J. Amer. Chem. Soc., 60, 309-319.

Bustillo, M.A. \& García-Romero, E. (2003): Arcillas fibrosas anómalas en encostramientos y sedimentos superficiales: características y génesis (Esquivias, Cuenca de Madrid). Bol. Soc. Esp. Cerám. Vidrio, 42, 289-297.

Callen, R.A. (1977): Late Cainozoic environments of part of northeastern South Australia. J. Geol. Soc. Aust., 100, 151-169.

Calvo, J.P., Blanc-Valleron, M.M., Rodríguez-Aranda, J.P., Rouchy, J.M., Sanz, M.E. (1999): Authigenic clay minerals in continental evaporitic environments. Spec. Publ. Int. Ass. Sediment., 27, 129-151.

Couture, R.A. (1977): Composition and origin of palygorskite-rich and montmorillonite-rich zeolite containing sediments from the Pacific Ocean. Chem. Geol., 19, 113-130.

Decarreau, A., Sautureau, J.P., Steinberg, M. (1975): Genèse des minéraux argileux du Bartonien moyen du Bassin de Paris. Bull. Soc. Fr. Minéral. Cristallogr., 98, 142-151.

El Prince, A.M., Mashhady, A.S., Aba-Husayn, M.M. (1979): The occurrence of pedogenic palygorskite (attapulgite) in Saudi Arabia. Soil Sci., 128, 211-218.

Eren, E., Kadir, S., Hatipoglu, Z., Gül, M. (2008): Quaternary calcrete development in the Mersin area, southern Turkey. Turkish J. Earth Sci., 17, 763-784.

Estéoule-Choux, J. (1984): Palygorskite in the Tertiary deposits of the Armorican Massif. in: "Palygorskite-Sepiolite: Occurrences, Genesis and Uses". Developments in Sedimentology, A. Singer, E. Galán, eds., Elsevier, New York, 75-82.

Fernandez Macarro, B., Armenteros, L., Blanco, J.A. (1988): Procesos de alteración y paleosuelos ligados a la sedimentación miocena del noreste de Segovia, Depresión del Duero. Acta Geol. Hispánica, 23, 269-281.

Galan, E. (1996): Properties and applications of palygorskitesepiolite clays. Clay Miner., 31, 443-453.

Galán, E. \& Castillo, A. (1984): Sepiolite-palygorskite in Spanish Tertiary basins: genetical patterns in continental environments. in: "Palygorskite-Sepiolite: Occurrences, Genesis and Uses". Developments in Sedimentology, A. Singer, E. Galán, eds., Elsevier, New York, 87-124.

Galán, E. \& Ferrero, A. (1982): Palygorskite-sepiolite clays of Lebrija, Southern Spain. Clays Clay Miner., 30, 191-199.

Galán, E. \& Pozo, M. (2011): Palygorskite and Sepiolite Deposits in Continental Environments. Description, Genetic Patterns and Sedimentary Settings. in: "Developments in PalygorskiteSepiolite research". Developments in Clay Science, 3, E. Galán \& A. Singer, eds., Elsevier, New York, 125-173. 
Galán, E., Brell, J.M., La Iglesia, A., Robertson, R.H.S. (1975): The Cáceres Palygorskite Deposits, Spain. in "1975 International Clay Conference, Mexico". Applied Publ., 91-94.

García-Romero, E (1988): Estudio mineralógico y estratigráfico de las arcillas de las facies centrales del Neógeno del borde sur de la Cuenca del Tajo. PhD, Editorial de la Universidad Complutense, Madrid, $441 \mathrm{p}$.

- (2012): Bentonitas del sureste de la Península Ibérica. Field trip guide. Workshop. Sociedad Española de Arcillas, 48 p.

García-Romero, E. \& Suárez, M. (2010): On the chemical composition of sepiolite and palygorskite. Clays Clay Miner., 58, 1-20.

—, - (2013): Sepiolite-palygorskite: Textural study and genetic considerations. Appl. Clay Sci., 86, 129-144.

_, _ (2014): Sepiolite-palygorskite polysomatic series: Oriented aggregation as a crystal growth mechanism in natural environments. Am. Mineral., 99, 1653-1661.

García-Romero, E., Suárez, M., Bustillo, M.A. (2004): Characteristics of a Palygorskite in Miocene rocks Madrid Basin (Spain). Clays Clay Miner., 52, 484-494.

García-Romero, E., Suárez, M., Oyarzun, R., López-García, J.A., Regueiro, M. (2006): Fault-hosted palygorskite from the Serrata de Nijar deformation zone (SE Spain). Clays Clay Miner., 54, 324-332.

Hutton, J.T. \& Dixon, J.C. (1981): The chemistry and mineralogy of some South Australian calcretes and associated soft carbonates and their dolomitization. J. Geol. Soc. Aust., 28, 71-80.

Islem, C., Kamel, J., Emna, F., Farkher, J., Adel, M. (2016): Use of Tunisian raw clay to remove dye from aqueous solution. Arab. J. Geosci., 9, 564.

Jamoussi, F., Ben Aboud, A., López-Galindo, A. (2003): Palygorskite genesis through silicate transformation in Tunisian continental Eocene deposits. Clay Miner., 38, 187-200.

Jones, B.F. (1986): Clay mineral diagenesis in lacustrine sediments. U. S. Geol. Surv. Bull., 1578, 291-300.

Jones, B.F. \& Galán, E. (1988): Sepiolite and palygorskite. in: "Hydrous Phyllosilicates", Reviews in Mineralogy, 19, Bailey S. W., ed., Mineralogical Society of America, Washington, 631-674.

Kadir, S., Eren, M., Külah, T., Önalgil, N., Cesur, M., Gürel, A. (2014): Genesis of Late Miocene-Pliocene lacustrine palygorskite and calcretes from Kursehir, Central Anatolia, Turkey. Clay Miner, 49, 473-494.

Kaplan, M.Y., Eren, M., Kadir, S., Kapur, S. (2013): Mineralogical, geochemical and isotopic characteristics of Quaternary calcretes in the Adana region, Southern Turkey: Implications on their origin. Catena, 101, 164-177.

Leguey, S., Pozo, M., Medina, J.A. (1985): Polygenesis of sepiolite and palygorskite in a fluvio-lacustrine environment in the Neogene basin of Madrid. Acta Petrol. Mineral., 29A, 287-301.

Leone, G., Reyes, E., Cortecci, G., Pochini, A., Linares, J. (1983): Genesis of bentonites from Cabo de Gata, Almeria, Spain: a stable isotope study. Clay Miner, 18, 227-238.

Lindgreen, H., Geiker, M., Krøyer, H., Springer, N., Skibsted, J. (2008): Microstructure engeneering of Portland cement pastes and mortars through addition of ultrafine layer silicates. Cem. Concr. Comp., 30, 686-699.

Liu, Y., Wang, W., Wang, A. (2012): Effect of dry grinding on the microstructure of palygorskite and adsorption efficiency for methylene blue. Powder Technol., 225, 124-129.
Liu, E., Sarkar, B., Wang, L., Naidu, R. (2016): Copper-complexed clay/poly-acrylic acid composites: Extremely efficient adsorbents of ammonia gas. App. Clay Sci., 121-122, 154-161.

López-Galindo, A., Viseras, C., Aguzzi, C., Cerezo, P. (2011): Pharmaceutical and cosmetic uses of fibrous clays. in: "Developments in Palygorskite-Sepiolite research". Developments in Clay Science, 13, E. Galán \& A. Singer, eds., Elsevier, New York, 290-324.

Mackenzie, R.C., Wilson, M.J., Mashhdy, A.S. (1984): Origin of palygorskite in some soils of the Arabian Peninsula. in: "Palygorskite-Sepiolite: Occurrences, Genesis and Uses". Developments in Sedimentology, A. Singer, E. Galán, eds., Elsevier, New York, 177-186.

Martín Pozas, J.M. (1968): Análisis cuantitativo por difracción de Rayos-X de filosilicatos de la arcilla. Ph.D, Universidad de Granada, Granada.

Martín Pozas, J.M., Sánchez Camazano, M., Martín Vivaldi, J.L. (1981): La palygorskita de Tabladillo (Guadalajara). Bol. Geol. Min., 92, 395-402.

Martínez Lope, M.J., Garcia González, M.T., Molina, E. (1995): Relationships between Geomorphology and Palaeoweatherings on the Hercynian basement in central Spain. A mineralogical and geochemical approach. Rev. Soc. Geol. España, 8, 127-136.

Millot, G. (1970): Geology of Clays. Springer Verlag, Chapman \& Hall, London, 429 p.

Murray, H.H. (2000): Traditional and new applications for kaolin, smectite, and palygorskite: a general overview. Appl. Clay Sci., 17, 207-221.

Murray, H.H., Pozo M., Galán, E. (2011): An Introduction to Palygorskite and Sepiolite Deposits. Location, Geology and Uses. in: "Developments in Palygorskite-Sepiolite research". Developments in Clay Science, 3, E. Galán and A. Singer, eds., Elsevier, New York, 85-100.

Paquet, H. (1970): Evolution géochimique des minéraux argileux dans les altérations et les sols des climats méditerranéens et tropicaux à saisons contrastées. Mem. Serv. Cart. Geol. Als. Lorr, 30, 206 p.

Pineda, A., Camarera, Y., Salazar, A. (2007): Memoria de la Hoja ${ }^{\circ}$ 427 (Medina del Campo). Mapa Geológico de España E. 1:50.000 (MAGNA), Segunda Serie, Primera edición. IGME, 75 p.

Pozo, M., Medina, A., Leguey, S. (1985): Mineralogénesis de palygorskita en la zona central de la Cuenca de Madrid. Bol. Soc. Esp. Miner, 8, 271-283.

Rodas, M., Luque, F.J., Mas, R, Garzón, M.G. (1994): Calcretes, palycretes and silcretes in the Paleogene detrial sediments of The Duero and Tajo Basins, Central Spain. Clay Miner, 29, 273-285.

Ruiz-Hitzky, E., Aranda, P., Álvarez, A., Santarén, J., EstebanCubillo, A. (2011): Advanced materials and new applications of sepiolite and palygorskite. in: "Developments in PalygorskiteSepiolite research”. Developments in Clay Science, 3, E. Galán \& A. Singer, eds., Elsevier, New York, 293-452.

Rusek, P., Hubicki Z, Wójcik, G., Debczak, A. (2009): Application of the FT-IR/PAS and DRS methods for studying heavy metal ions sorption on the inorganic sorbents. Acta Phys. Pol. A., 116, 407-409.

Rusmin, R. Sarkar, B., Biswas, B., Churchman, J., Liu, Y., Naidu, R. (2016): Structural, electrokinetic and surface properties of activated palygorskite for environmental application. Appl. Clay Sci., 134, 95-102. 
Sautereau, M. \& Decarreau, A. (1973): Genèse des minéraux argileux. Géochimie des éléments majeurs, du chrome et du vanadium dans le Bartonien moyen du Bassin de Paris. Thèse 3ème cycle, Univ. Paris-sud, Orsay, 79 p.

Shadfan, H. \& Dixon, J.B. (1984): Occurrence of palygorskite in the soils and rocks of the Jordan Valley. in: "Palygorskite-Sepiolite: Occurrences, Genesis and Uses". Developments in Sedimentology, A. Singer, E. Galán, eds., Elsevier, New York, 187-198.

Shi, Y., Yang, Z., Wang, B., An, H., Chen, Z., Cui, H. (2016): Adsoption and photocatalytic degradation of tetracycline hydrochloride using a palygorskite-supported $\mathrm{Cu}_{2} \mathrm{O}-\mathrm{TiO}_{2}$ composite. Appl. Clay Sci., 119, 311-320.

Singer, A. (1979): Palygorskite in sediments: detrital, diagenetic or neoformed-A critical review. Geol. Rund., 68, 996-1008.

Singer, A. (1984): Pedogenic palygorskite in the arid environment. in: "Palygorskite-Sepiolite: Occurrences, Genesis and Uses". Developments in Sedimentology, A. Singer, E. Galán, eds., Elsevier, New York, 169-177.

Singer, A. \& Norrish, K. (1974): Pedogenic palygorskite occurrences in Australia. Am. Miner., 59, 508-517.

Stathopoulou, E.T., Suárez, M., García-Romero, E., Sanchez del Río, M., Kacandes, G.H., Giois, V., Chryssikos, G.D. (2011): Trioctahedral entities in palygorskite: near-infrared evidence for sepiolite-palygorskite polysomatism. Eur. J. Mineral., 23, 567-576.

Stahr, K., Kühn, K., Trommler, K-H., Papenfu $\beta$, M., Singer, A. (2000): Palygorskite-cemented crusts (palycretes) in Southern Portugal. Aust. J. Soil Res., 38, 169-188.

Suárez, M. \& García-Romero, E. (2011): Advances in the crystal chemistry of sepiolite and palygorskite. in: "Developments in Palygorskite-Sepiolite research". Developments in Clay Science, 13, E. Galán and A. Singer, eds., Elsevier, New York. 3355.

Suárez, M. \& García-Romero, E. (2012): Variability of the surface properties of sepiolite. Appl. Clay Sci., 67-68, 72-82.

—, - (2013): Sepiolite-palygorskite: a continuous polysomatic series. Clays Clay Miner., 61, 461-472.

Suárez, M., Armenteros, I., Navarrete, J., Martín Pozas, J.M. (1989): El yacimiento de palygorskita de Bercimuel (Segovia, Spain). Génesis y propiedades tecnológicas. Stv. Geol. Salmant., 26, 2746.

Suárez, M., Elsass, F., Robert, M., Martín Pozas, J.M. (1994): Evidence of a precursor in the neoformation of palygorskite: New data by analytical electron microscopy. Clay Miner., 29, 255-264.

Suárez, M., Flores, L., Martín Pozas, J.M. (1995): Mineralogical data for palygorskite from Bercimuel (Segovia, Spain). Clay Miner., 30, 161-266.
Suárez, M., García-Romero, E., Sánchez del Río, M., Martinetto, P., Dooryhée, E. (2007): The effect of trioctahedral cations on the dimensions of the palygorskite cell. Clay Miner., 42, 287-297.

Tazaki, K., Fyfe, W.S., Heath, G.R. (1986): Palygorskite formed on montmorillonite in North Pacific deep-sea sediments. Appl. Clay Sci., 6, 197-216.

Tazaki, K., Fyfe, W.S., Tsuji, M., Katayama, K. (1987): TEM Observations of the smectite-to palygorskite transition in deep Pacific sediments. Appl. Clay Sci., 2, 233-240.

Thommes, M., Kaneko, K., Neimark, A.V., Olivier, J.P., RodríguezReinoso, F., Rouquerol, J., Sing, K.S.W. (2015): Physisorption of gases, with special reference to the evaluation of surface area and pore size distribution (IUPAC Technical Report). Pure App. Chem., 87, 1051-167.

Trauth, N. (1977): Argiles évaporitiques dans la sédimentation carbonatée et épicontinentale tertiaire: Bassin de Paris, Mormoiron et Salenelles (France), Ibel Ghassoul (Maroc). Sciences Géologiques. Mémoires, 49, 195 p.

Velde, B. (1985): Clay minerals: a physico-chemical explanation of their occurrences. in: "Developments in Sedimentology", 40, Elsevier, New York, 187-198.

Wang, W., Wang, F., Kang, Y., Wang, A. (2015): Nanoscale dispersion crystal bundles of palygorskite by associated modification with phytic acid and high-pressure homogeneization for enhanced colloidal properties. Powder Technol., 269, 85-92.

Watts, N.L. (1976): Paleopedogenic palygorskite from the basal PermoTriassic of northwest Scotland. Am. Mineral., 61, 299-302.

- (1980): Quaternary pedogenic palygorskite from the Kalahari (South Africa): mineralogy, genesis and diagenesis. Sedimentology, 27, 661-686.

Weaver, C.E. \& Beck, K.C. (1977): Miocene of the S.E. United States: a model for chemical sedimentation in a peri-marine environment. Sediment. Geol., 17, 1-234.

Webster, D.M. \& Jones, B.F. (1994): Paleoenvironmental implications of lacustrine clay minerals from the Double Lakes Formation, Southern High Plains, Texas. in: "Sedimentology and Geochemistry of Modern and Ancient Saline Lakes", Renault, R.W., Last, W.M., eds., SEPM Special Publication, Tulsa, 50, 159-168.

Xu, J., Zhang, J., Wang, Q., Wang, A. (2011): Disaggregation of palygorskite crystal bundles via high-pressure homogeneization. Appl. Clay Sci., 54, 118-123.

Yaalon, D.H. \& Wieder, M. (1976): Pedogenic palygorskite in some arid brown (calciorthid) soils of Israel. Clay Miner., 11, 73-80.

Received 30 January 2017

Modified version received 17 April 2017

Accepted 20 February 2018 